\title{
Effect of a temperature rise on metal toxicity for the aquatic biota:
} a systematic review

\author{
Efeito da elevação da temperatura sobre a toxicidade de metais para a biota aquática: uma revisão sistemática
} Carla Juliana Nin $^{1}$ (1), Suzelei Rodgher ${ }^{1}$ (1)

\begin{abstract}
A B S T R A C T
Ecosystems are subject to various stress factors, such as temperature rises due to climate changes and metal disposal. Thermal stress can amplify or mask the effects of metals on aquatic organisms. This study aims to carry out a systematic review on the effects of temperature rises due to climate changes on the toxicity of metals for freshwater organisms. Searches were made in different electronic databases and article selection was based on the following inclusion criteria: concordance with the question of a systematic review; publication in English, Spanish, and Portuguese between 1960 and 2020; and the use of standard methodology. Forty-three articles were included, which were classified with respect to the year and country of publication, test-organisms and metals studied, temperatures tested, and the effects observed. In $80 \%$ of the studies analyzed, a temperature rise was responsible for increasing the toxicity of metals for the aquatic organisms. The temperatures studied contemplated the temperature rise predicted by the Intergovernmental Panel for Climate Change at the end of the 21st century. Brazil stood out among the countries for having the greatest number of research studies in this area, although there is still the need for an increase in studies in tropical climate regions. Based on the literature review, it was shown that the metals most studied were copper and cadmium and the test-organisms most used in the research projects were fish. The information obtained from ecotoxicological studies is essential to predict the effects and prevent the risks associated with the metal contamination of aquatic ecosystems due to climate changes.
\end{abstract}

Keywords: ecotoxicology; climate changes; microalgae; zooplankton; fish.

\begin{abstract}
RE S U M O
Ecossistemas estão sujeitos a diversos estressores, como o aumento da temperatura em razão das mudanças climáticas e do lançamento de metais. $O$ estresse térmico pode amplificar ou mascarar os efeitos dos metais nos organismos aquáticos. Este estudo teve como objetivo realizar uma revisão sistemática dos efeitos do aumento da temperatura, associado às mudanças climáticas, na toxicidade dos metais para organismos de água doce. Foram realizadas buscas em diferentes bases de dados eletrônicas, e a seleção dos artigos teve como critérios de inclusão: concordância com a questão da revisão sistemática, publicação em inglês, espanhol e em português entre 1960 e 2020 e emprego de metodologias padronizadas. Incluíram-se 43 artigos, que foram classificados com relação ao ano e país de publicação, organismos-teste e metais estudados, temperaturas testadas e efeitos observados. Em $80 \%$ dos estudos analisados, o aumento da temperatura foi responsável por elevar a toxicidade dos metais para os organismos aquáticos. As temperaturas estudadas contemplam o aumento previsto pelo Painel Intergovernamental de Mudanças Climáticas no fim do século 21. O Brasil destaca-se entre os países com maior número de pesquisas nesta área, embora seja necessário o aumento dos estudos em regiões de clima tropical. Com base na revisão bibliográfica, constatou-se que os metais mais estudados foram o cobre e o cádmio, e os organismos-teste mais utilizados nas pesquisas foram os peixes. As informações obtidas com estudos ecotoxicológicos são essenciais para a previsão dos efeitos e a prevenção dos riscos associados à contaminação por metais dos ecossistemas aquáticos mediante as mudanças climáticas.
\end{abstract}

Palavras-chave: ecotoxicologia; mudanças climáticas; microalgas; zooplâncton; peixes.

\footnotetext{
${ }^{1}$ Institute of Science and Technology, Universidade Estadual Paulista "Júlio de Mesquita Filho" - São José dos Campos (SP), Brazil.

Correspondence address: Suzelei Rodgher - Rodovia Presidente Dutra, km 137,8 - Eugênio de Melo - CEP: 12247-004 - São José dos Campos (SP), Brazil. E-mail: suzelei.rodgher@unesp.br

Conflicts of interest: the authors declare that there are no conflicts of interest.

Funding: none.
}

Received on: 12/15/2020. Accepted on: 08/14/2021.

https://doi.org/10.5327/Z217694781010

(c) (i)

This is an open access article distributed under the terms of the Creative Commons license. 


\section{Introduction}

One important variable to be considered in aquatic ecosystems is the temperature, due to its importance in maintaining the species and the metabolism of the aquatic systems (Esteves, 2011). Climate change, deforestation of the riparian forest, the construction of reservoirs, canalization of aquatic bodies, and the disposal of hot water used in the refrigeration processes of refineries, steel mills, and thermoelectric plants are related to the temperature rise of aquatic systems (Qiu, 2012; Raptis et al., 2016).

The aquatic ecosystem biota is especially vulnerable to temperature variations since most of the species are ectothermic, that is, their body temperatures change with alterations in the environmental temperature (Hochachka and Somero, 2002) and temperature rises are associated with alterations in the distribution and a decline in the diversity of phytoplankton (Lenard et al., 2019), zooplankton (Adamczuk, 2016), and fish (Herrera-R et al., 2020) in freshwater systems.

Temperature rises and the entrance of pollutants are considered stressors that affect the occurrence of species in the ecosystems (Noyes and Lema, 2015; Gill et al., 2020). According to the fifth report of the Intergovernmental Panel for Climate Change (IPCC, 2014), the temperature rise could remain below $2^{\circ} \mathrm{C}$ in 2100 in a scenario of low greenhouse gas release, with the highest predicted increase being above $2^{\circ} \mathrm{C}$ in 2037 and more than $4.8^{\circ} \mathrm{C}$ in 2100 in a scenario of elevated gas emission. Freshwater ecosystems are particularly more sensitive to climate change due to the temperature rise and changes in the precipitation patterns and water flow (Da Silva et al., 2020).

An understanding of the consequences of releasing and dispersing pollutants in aquatic ecosystems is one of the challenges of aquatic ecotoxicology. Aquatic ecotoxicology is the study of the effects of toxic chemical substances on representative organisms of aquatic ecosystems (Hoffman et al., 2003). Aquatic organisms belonging to different trophic levels are used to evaluate the potential toxicity of environmental samples, effluents, and chemical substances. Toxicity tests should be carried out with species belonging to different trophic levels to cover the natural variability in sensitivity among the species (Zagatto and Bertoletti, 2006).

The diverse contaminants released into aquatic ecosystems metals are of special concern due to their persistence, bioaccumulation, and toxicity, demanding particular attention from the human and environmental health points of view (Ali et al., 2019). In aquatic ecosystems, metallic ions come from natural sources such as the weathering of rocks and soils, volcanic eruptions, and anthropogenic sources such as untreated industrial and domestic effluents, mining residues, the application of agricultural pesticides to crops, and rainfall in places with atmospheric pollution (Esteves, 2011; Amoatey and Baawain, 2019).

The aquatic biota is subject to a combination of stress agents. In this context, some studies have revealed that a temperature rise can increase the toxicity of some metals in freshwater organisms. In a study concerning the effects of high temperatures and exposure to copper on the microalgae Scenedesmus quadricauda, Yong et al. (2018) determined that the combination of these factors caused significant disturbances in the metabolism of the microalgae. Bae et al. (2016) also showed that a temperature rise of the water was responsible for increasing the toxicity of copper for the microcrustacean Daphnia magna. The same tendency was observed by Park et al. (2020) for the fish species Danio rerio, in a study aimed at determining any physiological damage in fish exposed to the metal lead and to high temperatures. According to Val et al. (2016), the interactions between metals, temperature, and organisms are too complex to predict the effects on the aquatic biota, since a temperature rise also stimulates detoxification processes and the excretion of certain metals by the individuals, reducing the toxicity of the metal ions.

Various reviews concerning different aspects of temperature rises in freshwater ecosystems due to climate change and thermal pollution (release of hot effluents from thermoelectric and hydroelectric factories) and their effects on hydrology, biogeochemistry (Xu et al., 2019; Copetti and Salerno, 2020), biological diversity (Madden et al., 2013; O'Briain, 2019), and the risks associated with human diseases (Ahmed et al., 2020) have been reported in the literature. Within this context, one of the important effects, as yet little studied, is the change in action of metals with a temperature rise, on aquatic organisms belonging to the different trophic levels. Metals are one of the stressors that affect aquatic ecosystems, and as the climate changes occur, it becomes necessary to understand the combined effect of the thermal and chemical stresses on the biota of these environments (Radinger et al., 2016). There are no studies that compare and discuss the combined effect of temperature rise and the presence of metals for representative species of freshwater ecosystems. From this perspective, systematic reviews make it possible to reunite and discuss the scientific evidence concerning the combined action of physical (temperature) and chemical (metal) stressors on the aquatic biota.

Based on the above, the goal of this study was to carry out a systematic review of the effects of a temperature rise on the toxicity of metals for freshwater organisms. The hypothesis presented was that a rise in temperature influences the toxicity of metals for aquatic organisms. In addition, some gaps in the literature were highlighted and recommendations made concerning new directions for future studies. Papers discussing studies concerning this theme are certainly important for students, professors, and researchers in environmental sciences.

\section{Methodology}

The steps of a systematic review contemplate the limits of the question (question formulated containing the description of the theme), search for evidence (identify the databases to be examined), review and selection of papers, and the checking of the methodological quality of the research and description of the results (Sampaio and Mancini, 2007). In this present survey, the guiding question was, What is the effect of a temperature rise on metal toxicity for the aquatic biota? Scientific articles available in the databases Scielo, Science Direct, Web of 
Science, and the Google Academic search system were used, as well as a search among the references of the selected articles. Articles published in English, Spanish, and Portuguese between 1960 and 2020 were analyzed. This period was chosen because the standardization of ecotoxicological research methodologies dates from the sixties (Zagatto and Bertoletti, 2006).

The following descriptors were used: "systematic review AND toxicity AND temperature," "toxicity AND algae AND temperature," "toxicity AND zooplankton AND temperature," "toxicity AND fish AND temperature," and "toxicity AND climate change AND metal." For the search according to the metals, the following descriptors were used: "toxicity AND metal AND temperature," and this structure was used for the search for the remaining metals of the periodic table.

During the selection of the studies, the articles were evaluated independently by two researchers, one being an undergraduate student in environmental engineering and the other a researcher in the same area, following the inclusion and exclusion criteria. An analysis of the titles and abstracts identified in the initial search was carried out. When the title and abstract were not explicative, the entire articles were analyzed. Divergencies were discussed. The inclusion and exclusion criteria were according to Martins and Carmo Junior (2018) and include:

- The question guiding the review (in agreement with the review question) and studies considering the effect of the exposure of freshwater organisms to metals at different temperatures were included. Studies concerning saltwater and land organisms were excluded as well as those that did not analyze the metal toxicity and articles already reviewed that were reselected during the search;

- Search period defined (60 years);

- Use of standardized methods and methodological criteria (described in articles, books, protocols, and research norms in the ecotoxicol- ogy area) according to standardization agencies such as American Society for Testing and Materials (ASTM), Associação Brasileira de Normas Técnicas (ABNT), Environment Canada, Organisation for Economic Co-operation and Development (OECD), International Organization for Standardization (ISO), Standard Methods (APHA), and the U.S. Environment Protection Agency (USEPA).

For the data analysis, the studies were separated in blocks distributed according to the publication year, country, and results encountered. Tables and graphs were also elaborated to analyze the number of publications per year, the articles published per country, and the effects observed on the test-species due to the combined exposure to high temperatures and metals.

\section{Results}

After carrying out the literature review in the databases, 218 articles were found as from the descriptors used. The abstracts were then read, and after applying the exclusion and inclusion criteria, 43 articles were selected.

Tables 1, 2 and 3 present the studies selected after the literature reviews for microalgae, zooplankton, and fish, respectively, and their descriptions per author, year, country, test-organism, metal, temperature tested, and effect were observed.

Based on the review carried out, 4 studies were published before 2000, 12 between 2000 and 2009, and 27 as from 2010 (Figure 1).

As shown in Figure 2, the articles were published in 19 different countries and most of the studies found in this review were published in Belgium (6), Brazil (6), the USA (4), and France (4).

With respect to the distribution of studies per continent, Europe published the largest number of articles (17) on the subject, followed

Table 1 - Studies with microalgae test-organisms and principal characteristics.

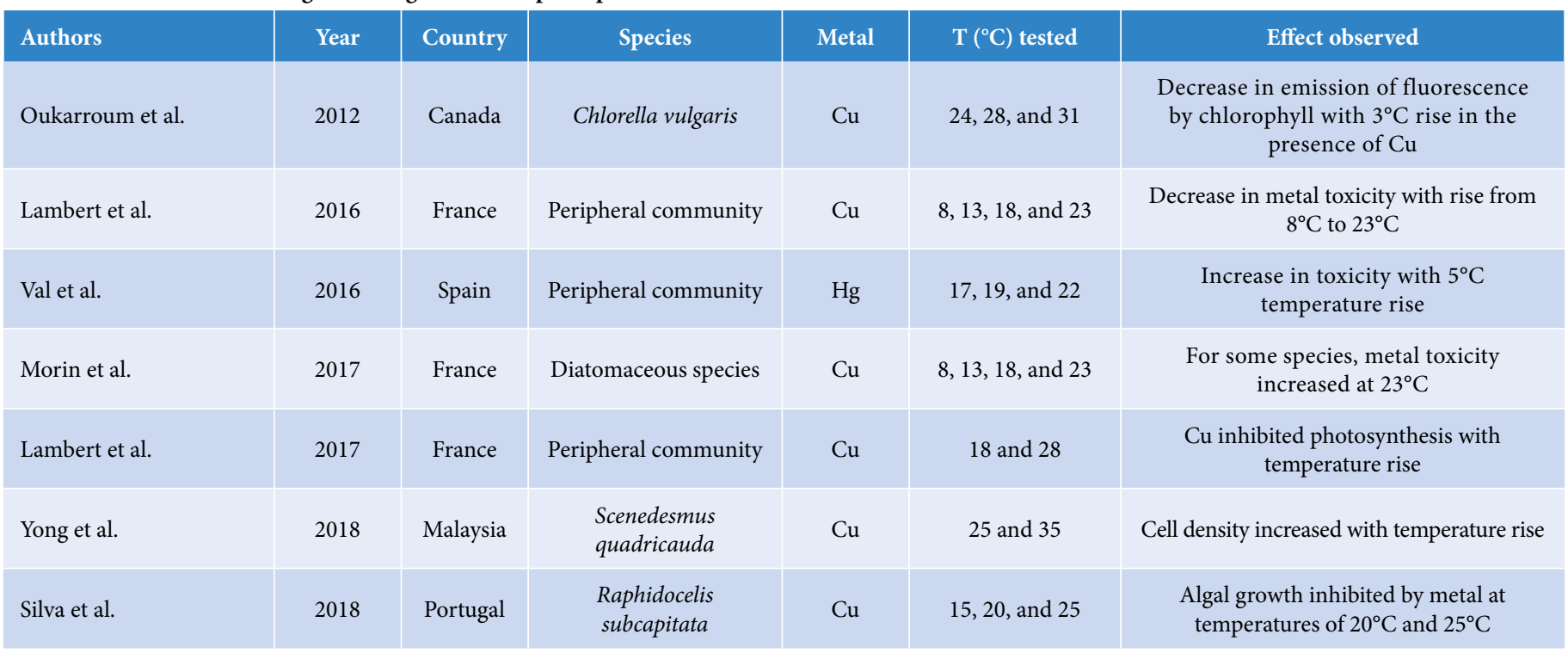


Table 2 - Studies with zooplankton test-organisms and principal characteristics.

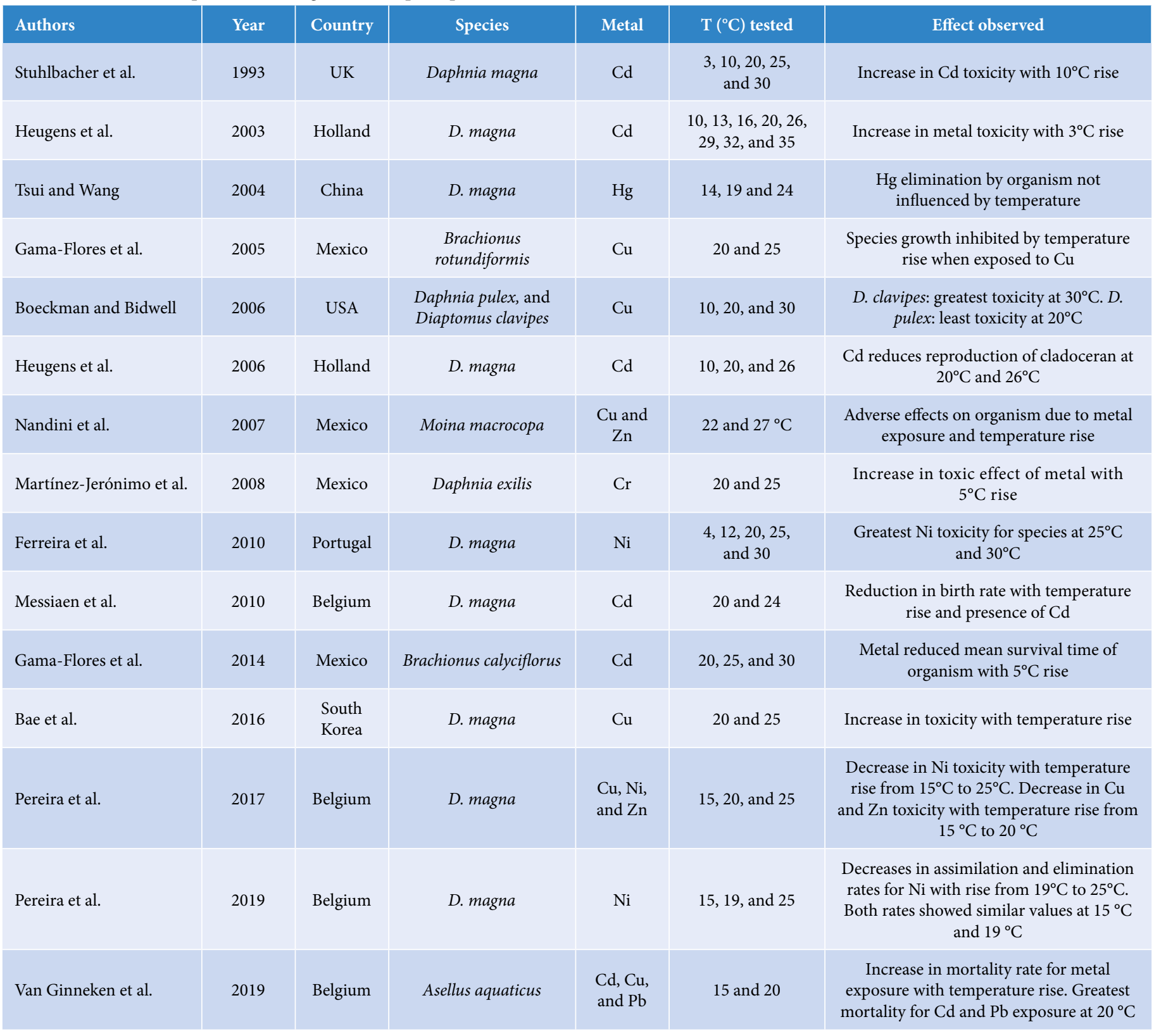

by North America (8). No studies were found concerning this question in Oceania.

Of the test-species employed in the studies, fish were the most used (21), followed by zooplankton (15) and microalgae (7). Of the zooplankton species used, the microcrustacean $D$. magna was the most used, corresponding to $64 \%$ of the studies carried out with cladocerans. Of the 55 species studied, 33 were from temperate regions and 22 from tropical regions, a result compatible with the numbers of studies carried out in these regions, since $53.8 \%$ of the studies were carried out in Europe and North America. Most of the species of tropical origin studied were fish, where 18 species of tropical origin were included. Nine metals were studied in the articles analyzed: aluminum, arsenic, cadmium, lead, copper, chromium, mercury, nickel, and zinc. Of these, the elements most frequently studied were copper (20 articles) and cadmium (15 articles).

Another aspect considered referred to acclimatation of the test-organisms to the temperatures tested before starting the toxicity. Of the 43 studies analyzed, 20 carried out acclimatation, corresponding to 
Table 3 - Studies with fish test-organisms and principal characteristics.

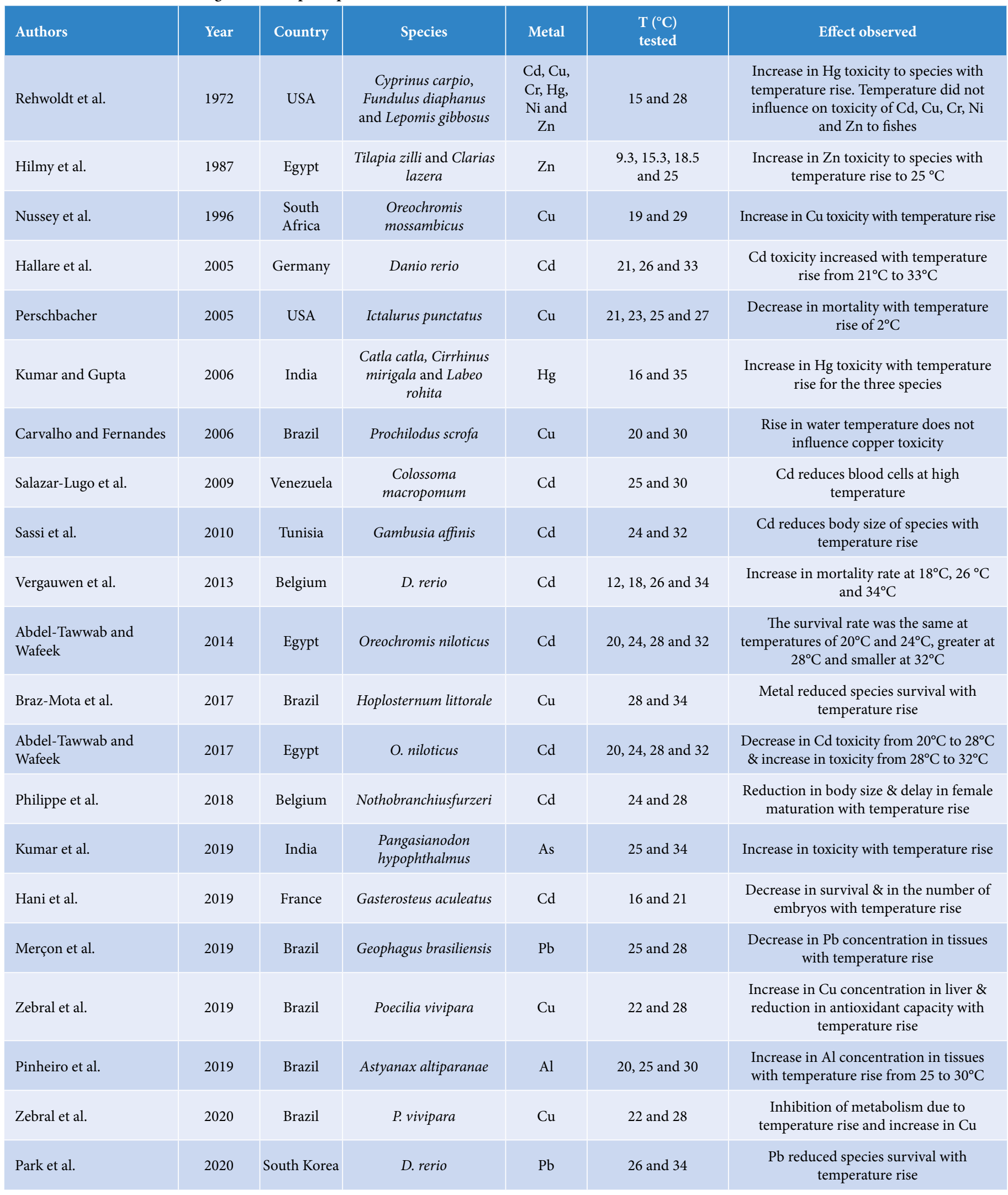




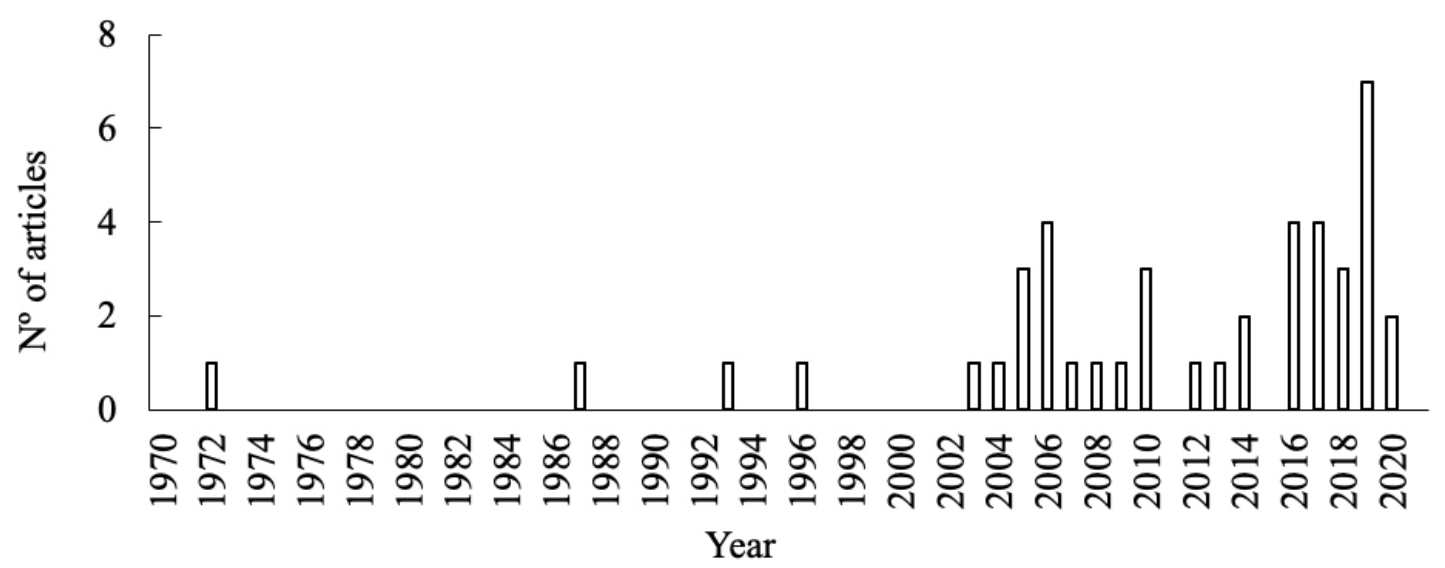

Figure 1 - Number of articles published per year.

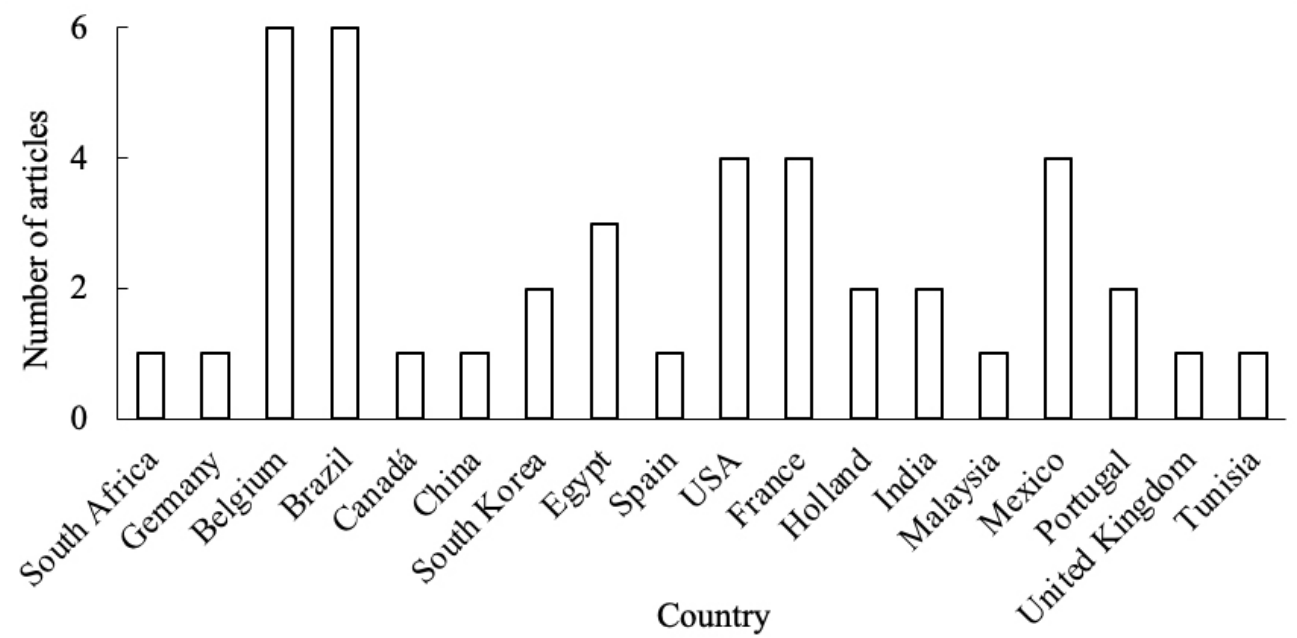

Figure 2 - Number of articles published per country.

$45.45 \%$ of the articles. The proportion of studies which acclimatized the organisms decreased as the years went by, being $60 \%$ before 2000 , $50 \%$ between 2000 and 2010, and $40.74 \%$ as from 2010 .

Based on the literature review carried out, the influence of temperature on metal toxicity for the test-organisms was studied (Table 4). For all the groups of organisms, the main effect observed was an increase in toxicity of the metals analyzed with rise in temperature $-71.4 \%$ of the articles used microalgae, $86.7 \%$ zooplankton, and $77.3 \%$ fish. Of the studies carried out with zooplankton and fish, 6.7 and $4.6 \%$, respectively, showed no variation in the toxicity of the metal analyzed with rise in temperature. In addition, $4.5 \%$ of the studies with fish first observed a decrease followed by an increase in metal toxicity with temperature rise.
Table 4 - Effect observed (in percent articles) on the test-organisms with temperature rise.

\begin{tabular}{|l|c|c|c|}
\hline Effect observed & Microalgae & Zooplankton & Fish \\
\hline Increase in toxicity & 71.4 & 86.7 & 77.3 \\
\hline Decrease in toxicity & 28.6 & 6.6 & 13.6 \\
\hline Decrease followed by increase & - & - & 4.5 \\
\hline No variation & - & 6.7 & 4.6 \\
\hline
\end{tabular}

For the groups of microalgae and zooplankton studied, effects on metal toxicity were observed as from a rise of $2^{\circ} \mathrm{C}$. However, for most of the studies carried out with these organisms, a variation in metal 
toxicity was only observed with a temperature rise of $5^{\circ} \mathrm{C}$. With respect to the studies with fish, differences in metal toxicity occurred as from a temperature rise of $4^{\circ} \mathrm{C}$, and the main variation in temperature studied was between 5 and $7^{\circ} \mathrm{C}$.

\section{Discussion}

In this systematic review, a comparative analysis was carried out between the studies which analyzed the effects of temperature rises on metal toxicity for different groups of aquatic organisms. The present investigation provided evidence that in $80 \%$ of the studies analyzed, a temperature rise was responsible for increasing the toxicity of metals for the aquatic organisms studied. The data published in this review also indicated an increase over the past few decades in the number of research projects concerning the effects of temperature rises on metal toxicity for aquatic organisms. This increasing concern of the scientific community in understanding the combined effect of temperature rises of the water and aquatic contaminants occurred due to some studies and forecasts showing that thermal pollution and climate changes are threats to biodiversity (Cardoso-Mohedano et al., 2015; Gill et al., 2020). The current rise in the water temperature already exceeds the capacity of some species to adapt, causing changes in the structure and functions of aquatic ecosystems (Schiedek et al., 2007; Pound et al., 2021).

Despite the increase in number of articles published over the past few decades concerning the influence of temperature on the action of metals, there are still some questions that need to be approached concerning the countries where the studies were developed, the test-organisms employed, and the metals studied.

The present survey demonstrated that most of the scientific investigations were carried out by research institutions in countries with temperate climates, as compared to the amount produced in countries with tropical climates. Thus, research on the potential effects of contaminants on the biota have concentrated on species and test conditions representative of temperate regions (Daam et al., 2020). Of the South American countries, Brazil had the largest number of articles published on this theme. The absence of studies in Oceania and the scarcity of studies in Africa and South America revealed the need to amplify investment in the ecotoxicology area in regions with tropical climates, since species from regions with different climatic characteristics do not react in the same way to temperature rises or a combination of this factor with exposure to metals (Graham and Harrod, 2009). For this reason, the use of results obtained for temperate region species to predict risks for the tropical fish biota should be done with caution. The use of native species can provide more realistic results concerning the toxicity of chemical agents, since they reflect local environmental conditions (Harmon et al., 2003; Raymundo et al., 2019).

With respect to the groups of organisms tested, it is important to note the scarcity of studies on microalgae. These organisms are the base of the food chain in aquatic ecosystems, and toxic effects in their com- munities can influence the upper trophic levels (Wetzel, 2001). On the other hand, fish were the test-organisms most studied in the theme of this review. There is adequate knowledge for some fish species and their cultivation presents a low level of difficulty, showing ecological and commercial importance (Zagatto and Bertoletti, 2006; Esteves, 2011). Nevertheless, the toxic effects of metals associated with thermal stress should be evaluated in species from different trophic levels, due to variation in sensitivity to the contaminants (Hoffman et al., 2003) and in the thermal tolerance limits (Silva et al., 2020) existent among the organisms, and also the accumulation of metals via the trophic chain (DeForest and Meyer, 2015). Hence, studies with microalgae must be amplified and the species used within each group of test-organism diversified.

The literature survey indicated a predominance of studies on the metals copper and cadmium and the absence of research on other metals. Copper, an essential micronutrient for the organisms in determined concentrations, was the metal most used in research with the three groups of test-organisms evaluated. Cadmium, differently from copper, has no known metabolic function and is toxic even in low concentrations. Both metals reached the water bodies via the discharge of industrial effluents and by way of mining residues (Vardhan et al., 2019). The fact that these metals were the most used in the research projects found in this review can be explained by the great number of studies concerning these elements already existent, making data collection, comparative analysis, and a discussion based on already published articles much easier. Based on the finding of the present survey, the authors consider it necessary to amplify investigations concerning the effect of temperature rises on the action of other metals, for example, aluminum, chromium, lead, iron, manganese, and nickel. These metals come from mining, electroplating, civil construction, tanneries, and the production of pigments, batteries, metal alloys, and agrochemicals and can enter aquatic systems via direct or indirect ways (Azevedo and Chasin, 2003).

The research projects analyzed reported the effects on metal toxicity as from $3^{\circ} \mathrm{C}$ temperature rises for microalgae and zooplankton, and as from $4^{\circ} \mathrm{C}$ rises for fish, in experiments carried out in laboratories. Therefore, the temperature ranges studied contemplated the temperature rises predicted by the IPCC (2014) at the end of the 21 st century. In ecotoxicological studies carried out under laboratory conditions, the test-species are exposed to the chemical agents at the standard temperature, within the temperature range considered adequate for the organisms (Zagatto and Bertoletti, 2006). The evident impact of temperature rises on the toxicity of chemicals, as revealed by the present systematic review, emphasizes the need for the standard protocols in the area to consider standard temperatures and those to be registered under natural conditions.

With respect to acclimatation of the species to the temperatures, in recent years, the number of research projects with acclimatized organisms for toxicity studies has decreased. Acclimatation is necessary to guarantee that the toxic effects observed in the experiments are a consequence of the metal toxicity at high temperature, without the occurrence 
of thermal shock by the individual. The acclimatation potential of organisms is an aspect of global climate changes that should be considered in the studies (Delorenzo, 2015). According to Silva et al. (2020), acclimatation can collaborate to a better understanding of the strategies used by organisms to deal with environmental changes, considering their capacity to adapt to unfavorable environmental conditions. It is, therefore, fundamental that future research considers the acclimatation of the organisms, guaranteeing that the results obtained are more representative.

The present review also indicated adverse effects on the test-species due to temperature rises in the medium and their association with an intensification of the toxicity of the metals. For microalgae, the increase in metal toxicity with temperature rise was due to a decrease in photosynthetic efficiency (Oukarroum et al., 2012) and to growth inhibition due to metabolic changes and in the levels of amino acids, fatty acids, and sugars (Yong et al., 2018). For zooplankton, it was observed that the increase in toxicity due to a temperature rise was due to a greater accumulation of metal, protein denaturation, and a destabilization of homeostasis, with a reduction in reproduction and survival (Lannig et al., 2006). For fish, the increase in metal toxicity due to the temperature rise was due to an accumulation of metal in different body tissues and a reduction in the metabolism and antioxidant capacity of the organisms to deal with the metal toxicity (Pinheiro et al., 2019; Zebral et al., 2019). In consequence, the heartbeat was reduced, bad body formation and reproductive damage occurred, and the fish mortality rates were high (Park et al., 2020). Thus, considering the toxic effects registered in important representatives of the biota of aquatic systems, the loss of the ecosystem services they offer is likely to occur under possible climate change scenarios in metal-containing environments.

Considering that the duration and intensity of heat waves will probably increase in coming decades as a function of climate change, this increases the concern with the potential effects of a simultaneous temperature rise and pollution of aquatic environments and emphasizes the need for wider environmental monitoring to better forecast the impacts on the biota (Jacquin et al., 2019). Thus, an adequate protection of the biodiversity depends on the advance of research concerning the sensitivity of aquatic organisms to different pollutants (metals, agrochemicals, nanoparticles, for example) under current climatic conditions and under those projected for the future, and of the population's ability to understand the possible effects of changes to the ecosystems when faced with this scenario.

\section{Conclusions}

There is evidence that temperature rises can increase or decrease the effects of metals on aquatic organisms and can also show no influence on these contaminants. This systematic review showed that according to most of the studies concerning the effects of metals with temperature rises, there was an increase in toxicity for microalgae, zooplankton, and fish species. In addition, an increase in interest concerning this theme within the scientific community was found, possibly due to the increase in importance given to questions of climate change and to the increase in research institutions and the training of human resources. Despite the increase in publications in recent decades, there is a need to amplify the number of metals and organisms analyzed. Attention should be given to the diversification of the test-organisms studied, principally among the bacterioplankton, phytoplankton, and zooplankton species.

It is important to acclimatize the individuals, such that the laboratory conditions represent the stress factors found in the natural environment in the most realistic manner. There is also a need for research that improves the understanding of the effects of temperature on the toxicity of other aquatic contaminants. Considering the temperature rise predicted for future decades due to climate change, an advance in research concerning the effects of temperature rises associated with chemical stressors on aquatic biodiversity is primordial, especially in tropical regions. Ecotoxicological analyses are of great importance in forecasting and preventing threats associated with the contamination of water bodies by toxic agents within the scenario of climate change.

\section{Contribution of authors:}

Nin, C.J: Conceptualization, Methodology, Formal analysis, Writing - original draft. Rodgher, S: Conceptualization, Supervision, Writing - original draft, Writing - review \& editing.

\section{References}

Abdel-Tawwab, M.; Wafeek, M., 2014. Influence of water temperature and waterborne cadmium toxicity on growth performance and metallothionein-cadmium distribution in different organs of Nile tilapia, Oreochromis niloticus (L.). Journal of Thermal Biology, v. 45, 157-162. https://doi.org/10.1016/j.jtherbio.2014.09.002.

Abdel-Tawwab, M.; Wafeek, M., 2017. Fluctuations in water temperature affected waterborne cadmium toxicity: Hematology, anaerobic glucose pathway, and oxidative stress status of Nile tilapia, Oreochromis niloticus (L.). Aquaculture, v. 477, 106-111. https://doi.org/10.1016/j.aquaculture.2017.05.007.
Adamczuk M., 2016. Past, present, and future roles of small cladoceran Bosmina longirostris (O. F. Muller, 1785) in aquatic ecosystems. Hydrobiologia, v. 767, 1-11. https://doi.org/10.1007/s10750-015-2495-7.

Ahmed, T.; Zounemat-Kermani, M.; Scholz, M., 2020. Climate change, water quality and water-related challenges: a review with focus on Pakistan. International Journal of Environmental Research and Public Health, v. 17, (22), 8518. https://doi.org/10.3390/ ijerph 17228518 . 
Ali, H.; Khan, E.; Ilahi I., 2019. Environmental chemistry and ecotoxicology of hazardous heavy metals: environmental persistence, toxicity, and bioaccumulation. Journal of Chemistry, v. 2019, 6730305. https://doi. org/10.1155/2019/6730305.

Amoatey, P.; Baawain, M. S., 2019. Effects of pollution on freshwater aquatic organisms, Water Environment Research, v. 91, (10), 1272-1287. https://doi. org/10.1002/wer.1221.

Azevedo, F.A.; Chasin, A.A.M., 2003. Metais. Gerenciamento da Toxicidade. Atheneu InterTox, São Paulo, 554 pp.

Bae, E.; Samanta P.; Yoo J.; Jung J., 2016. Effects of multigenerational exposure to elevated temperature on reproduction, oxidative stress, and $\mathrm{Cu}$ toxicity in Daphnia magna. Ecotoxicology and Environmental Safety, v. 132, 366-371. https://doi.org/10.1016/j.ecoenv.2016.06.034.

Boeckman, CJ.; Bidwell, J.R., 2006. The effects of temperature, suspended solids, and organic carbon on copper toxicity to two aquatic invertebrates. Water, Air, \& Soil Pollution, v. 171, (1-4), p. 185-202. https://doi.org/10.1007/ s11270-005-9036-3.

Braz-Mota, S.; Fé, L.M.L.; Delunardo, F.A.C.; Sadauskas-Henrique, H.; Almeida-Val, V.M.F.; Val, A.L., 2017. Exposure to waterborne copper and high temperature induces the formation of reactive oxygen species and causes mortality in the Amazonian fish Hoplosternum littorale. Hydrobiologia, v. 789, (1), 157-166. https://doi.org/10.1007/s10750-016-2847-y.

Cardoso-Mohedano, J.G.; Bernardello, R.; Sanchez-Cabeza, J.A.; RuizFernández, A.C.; Alonso-Rodriguez, R.; Cruzado, A., 2015. Thermal impact from thermoelectric power plant on tropical coastal lagoon. Water, Air, \& Soil Pollution, v. 226, (1), 2202. https://doi.org/10.1007/s11270-014-2202-8.

Carvalho, C.S.; Fernandes, M.N., 2006. Effect of temperature on copper toxicity and hematological responses in the neotropical fish Prochilodus scrofa at low and high pH. Aquaculture, v. 251, (1), 109-111. https://doi. org/10.1016/j.aquaculture.2005.05.018.

Copetti, D.; Salerno, F., 2020. Climate-water-ecosystem-interactions: insights from four continent's case studies. Water, v. 12, (5), 1445. http://doi. org/10.3390/w12051445.

Daam, M.A.; Garcia, M.V.; Scheffczyk, A.; Römbke, J., 2020. Acute and chronic toxicity of the fungicide carbendazim to the earthworm Eisenia fetida under tropical versus temperate laboratory conditions. Chemosphere, v. 255, 126871. https://doi.org/10.1016/j.chemosphere.2020.126871.

Da Silva, G.; Silveira, C.; Silva, M.; Marcos Júnior, A.; Souza Filho, F.; Guimarães, S., 2020. Analysis of climate change projections on precipitation and temperature in Brazilian hydrographic regions for the 21st century. Brazilian Journal of Environmental Sciences (Online), v. 55, (3), 420-436. https://doi.org/10.5327/Z2176-947820200624.

DeForest, D.K.; Meyer, J.S., 2015. Critical review: toxicity of dietborne metals to aquatic organisms. Critical Reviews in Environmental Science and Technology, v. 45, (11), 1176-1241. http://dx.doi.org/10.1080/10643389.2014. 955626 .

Delorenzo, M.E., 2015. Impacts of climate change on the ecotoxicology of chemical contaminants in estuarine organisms. Current Zoology, v. 61, (4), 641-652. https://doi.org/10.1093/czoolo/61.4.641.

Esteves, F.A., 2011. Fundamentos de limnologia. Interciência, Rio de Janeiro, $790 \mathrm{pp}$.

Ferreira, A.L.G.; Serra, P.; Soares, M.V.M.; Loureiro, S., 2010. The influence of natural stressors on the toxicity of nickel to Daphnia magna. Environmental Science and Pollution Research, v. 17, (6), 1217-1229. https://doi.org/10.1007/ s11356-010-0298-y.
Gama-Flores, J.L.; Salas, M.E.H.; Sarma, S.S.S., 2014. Combined effects of temperature (level and oscillation) and cadmium concentration on the demography of Brachionus calyciflorus (Rotifera). International Review of Hydrobiology, v. 99, (1-2), 173-177. https://doi.org/10.1002/ iroh.201301722.

Gama-Flores, J.L.; Sarma, S.S.S.; Nandini, S., 2005. Interaction among copper toxicity, temperature and salinity on the population dynamics of Brachionus rotundiformis (Rotifera). Hydrobiologia, v. 546, (1), 559-568. https://doi. org/10.1007/s10750-005-4300-5.

Gill, K.C.; Fovargue, R.E.; Neeson, T.M., 2020. Hotspots of species loss do not vary across future climate scenarios in a drought-prone river basin. Ecology and Evolution, v. 10, (17), 9200-9213. https://doi.org/10.1002/ece3.6597.

Graham, C.T.; Harrod, C., 2009. Implications of climate change for the fishes of the British Isles. Journal of Fish Biology, v. 74, (6), 1143-1205. https://doi. org/10.1111/j.1095-8649.2009.02180.x.

Hallare, A.V.; Schirling, M.; Luckenbach, I.; Köhler, H.-R.; Triebskorn, R., 2005. Combined effects of temperature and cadmium on developmental parameters and biomarker responses in zebrafish (Danio rerio) embryos. Journal of Thermal Biology, v. 30, (1), 7-17. https://doi.org/10.1016/j. jtherbio.2004.06.002.

Hani, Y.M.I.; Turies, C.; Palluel, O.; Delahaut, L.; Bado-Nilles, A.; Geffard, A.; Dedourge-Geffard, O.; Porcher, J.M., 2019. Effects of a chronic exposure to different water temperatures and/or to an environmental cadmium concentration on the reproduction of the threespine stickleback (Gasterosteus aculeatus). Ecotoxicology and Environmental Safety, v. 174, 48-57. https://doi. org/10.1016/j.ecoenv.2019.02.032.

Harmon, S.M.; Specht, W.L.; Chandler, G.T.A., 2003. Comparison of the daphnids Ceriodaphnia dubia and Daphnia ambigua for their utilization in routine toxicity testing in the Southeastern United States. Archives of Environmental Contamination and Toxicology, v. 45, (1), 0079-0085. https:// doi.org/10.1007/s00244-002-0116-8.

Herrera-R, G.A.; Oberdorff, T.; Anderson, E.P.; Brosse, S.; Carvajal-Vallejos, F.M.; Frederico, R.G.; Hidalgo, M.; Jézéquel, C.; Maldonado, M.; MaldonadoOcampo, J.A.; Ortega, H.; Radinger, J.; Torrente-Vilara, G.; Zuanon, J.; Tedesco, P.A., 2020. The combined effects of climate change and river fragmentation on the distribution of Andean Amazon fishes. Global Change Biology, v. 26, (10), 5509-5523. https://doi.org/10.1111/gcb.15285.

Heugens, E.H.W.; Jager, T.; Creyghton, R.; Kraak, M.H.S.; Hendriks, A.J.; Van Straalen, N.M.; Admiraal, W., 2003. Temperature-dependent effects of cadmium on Daphnia magna: accumulation versus sensitivity. Environmental Science \& Technology, v. 37, (10), 2145-2151. https://doi.org/10.1021/ es0264347.

Heugens, E.H.W.; Tokkie, L.T.B.; Kraak, M.H.S.; Hendriks, A.J.; Van Straalen, N.M.; Admiraal, W., 2006. Population growth of Daphnia magna under multiple stress conditions: joint effects of temperature, food, and cadmium. Environmental Toxicology and Chemistry, v. 25, (5), 1399-1407. https://doi. org/10.1897/05-294R.1.

Hilmy, A.M.; El-Domiaty, N.A.; Daabees, A.Y.; Latife, H.A., 1987. Toxicity in Tilapia zilli and Clarias lazera (Pisces) induced by zinc, seasonally. Comparative biochemistry and physiology. C, Comparative Pharmacology and Toxicology, v. 86, (2), 263-265. https://doi.org/10.1016/0742-8413(87)90077-6.

Hochachka, P.W.; Somero, G.N., 2002. Biochemical adaptation: mechanism and process in physiological evolution. Oxford University Press, New York, 480 pp.

Hoffman, D.J.; Rattner, B.A.; Burton Jr., A.; Cairns, J.C., 2003. Handbook of ecotoxicology. Taylor \& Francis Group, New York, 1312 pp. 
Intergovernmental Panel on Climate Change - IPCC. 2014. Climate Change 2014: impacts, adaptation, and vulnerability. Global and Sectoral Aspects. Contribution of Working Group II to the Fifth Assessment Report of the Intergovernmental Panel on Climate Change. Cambridge University Press, United Kingdom and New York, 1132 pp.

Jacquin, L.; Gandar, A.; Aguirre-Smith, M.; Perrault, A.; Le Hénaff, M.; De Jong, L.; Paris-Palacios, S.; Laffaille, P.; Jean, S., 2019. High temperature aggravates the effects of pesticides in goldfish. Ecotoxicology and Environmental Safety, v. 172, 255-264. https://doi.org/10.1016/j.ecoenv.2019.01.085.

Kumar, A.; Gupta, A. K., 2006. Acute toxicity of mercury to the fingerlings of Indian major carps (catla, rohu and mrigal) in relation to water hardness and temperature. Journal of Environmental Biology, v. 27, (1), 89-92.

Kumar, N.; Gupta, S.K.; Bhushan, S.; Singh, A., 2019. Impacts of acute toxicity of arsenic (III) alone and with high temperature on stress biomarkers, immunological status and cellular metabolism in fish. Aquatic Toxicology, v. 214, 105233. https://doi.org/10.1016/j.aquatox.2019.105233.

Lambert, A.S.; Dabrin, A.; Morin, S.; Gahou, J.; Foulquier, A.; Foulquier, A.; Coquery, M.; Pesce, S., 2016. Temperature modulates phototrophic periphyton response to chronic copper exposure. Environmental Pollution, v. 208, (part B), 821-829. https://doi.org/10.1016/j.envpol.2015.11.004.

Lambert, A.S.; Dabrin, A.; Foulquier, A.; Morin, S.; Rosy, C.; Coquery, M.; Pesce, S., 2017. Influence of temperature in pollution-induced community tolerance approaches used to assess effects of copper on freshwater phototrophic periphyton. Science of the Total Environment, v. 607-608, 10181025. https://doi.org/10.1016/j.scitotenv.2017.07.035.

Lannig, G.; Cherkasov, A.S.; Sokolova, I.M., 2006. Temperature-dependent effects of cadmium on mitochondrial and whole-organism bioenergetics of oysters (Crassostrea virginica). Marine Environmental Research, v. 62, (suppl. 1), S79-S82. https://doi.org/10.1016/j.marenvres.2006.04.010.

Lenard, T.; Ejankowski, W.; Poniewozik, M., 2019. Responses of phytoplankton communities in selected eutrophic lakes to variable weather conditions. Water, v. 11, (6), 1207. https://doi.org/10.3390/w11061207.

Madden, N.; Lewis, A.; Davis, M., 2013. Thermal effluent from the power sector: an analysis of once-through cooling system impacts on surface water temperature. Environmental Research Letters, v. 8, (3), 035006. https://doi. org/10.1088/1748-9326/8/3/035006.

Martínez-Jerónimo, F.; Rodríguez-Estrada, J.; Martínez-Jerónimo, L., 2008. Daphnia exilis Herrick, 1895 (Crustacea: Cladocera). una especie zooplanctónica potencialmente utilizable como organismo de prueba en bioensayos de toxicidad aguda en ambientes tropicales y subtropicales. Revista Internacional de Contaminación Ambiental, v. 24, (4), 153-159.

Martins, T.S.; Carmo Junior, G.N.R., 2018. Avaliação de impacto ambiental: uma revisão sistemática sob a ótica metodológica. E\&S Engineering and Science, v. 7, (2), 29-41. https://doi.org/10.18607/ES201876616.

Merçon, J.; Pereira, M.P.; Passos, L.S.; Lopes, I.O.; Coppo, G.; Barbosa, B.; Cabral, D.; Gomes, C.G.L., 2019. Temperature affects the toxicity of lead-contaminated food in Geophagus brasiliensis (QUOY \& GAIMARD, 1824). Environmental Toxicology and Pharmacology, v. 66, 75-82. https://doi.org/10.1016/j.etap.2018.12.013.

Messiaen, M.; De Schamphelaere, K.A.C.; Muyssen, B.T.A.; Janssen, C.R., 2010. The micro-evolutionary potential of Daphnia magna population exposed to temperature and cadmium stress. Ecotoxicology and Environmental Safety, v. 73, (6), 1114-1122. https://doi.org/10.1016/j.ecoenv.2010.05.006.

Morin, S.; Lambert, A.S.; Rodriguez, P.; Dabrin, A.; Coquery, M.; Pesce, S., 2017. Changes in copper toxicity towards diatom communities with experimental warming. Journal of Hazardous Materials, v. 334, 223-232. https://doi.org/10.1016/j.jhazmat.2017.04.016.
Nandini, S.; Picazo-Paez, E.A.; Sarma, S.S.S., 2007. The combined effects of heavy metals (copper and zinc), temperature and food (Chlorella vulgaris) level on the demographic characters of Moina macrocopa (Crustacea: Cladocera). Journal of Environmental Science and Health, Part A, v. 42, (10), 1433-1442. https://doi.org/10.1080/10934520701480789.

Noyes, P.D.; Lema, S.C., 2015. Forecasting the impacts of chemical pollution and climate change interactions on the health of wildlife. Current Zoology, v. 61, (4), 669-689. https://doi.org/10.1093/czoolo/61.4.669.

Nussey, G.; Vuren, J.H.J.V.; Preez, H.H.D., 1996. Acute toxicity tests of copper on juvenile Mozambique tilapia, Oreochromis mossambicus (Cichlidae), at different temperatures. South African Journal of Wildlife Research, v. 26, (2), 47-55. https://hdl.handle.net/10520/EJC116995.

O'Briain, R., 2019. Climate change and European rivers: an ecohydromorphological perspective. Ecohydrology, v. 12, (5), e2099. https://doi. org/10.1002/eco.2099.

Oukarroum, A.; Perreault, F.; Popovic, R., 2012. Interactive effects of temperature and copper on photosystem II photochemistry in Chlorella vulgaris. Journal of Photochemistry and Photobiology B: Biology, v. 110, 9-14. https://doi.org/10.1016/j.jphotobiol.2012.02.003.

Park, K.; Han, E.J.; Ahn, G.; Kwak, I.-S., 2020. Effects of thermal stress-induced lead $(\mathrm{Pb})$ toxicity on apoptotic cell death, inflammatory response, oxidative defense, and DNA methylation in zebrafish (Danio rerio) embryos. Aquatic Toxicology, v. 224, 105479. https://doi.org/10.1016/j.aquatox.2020.105479.

Pereira, C.M.S.; Blust, R.; De Schamphelaere, K.A.C., 2019. Effect of temperature on nickel uptake and elimination in Daphnia magna. Environmental Toxicology and Chemistry, v. 38, (4), 784-793. https://doi. org/10.1002/etc.4352.

Pereira, C.M.S.; Deruytter, D.; Blust, R.; De Schamphelaere, K.A.C., 2017. Effect of temperature on chronic toxicity of copper, zinc, and nickel to Daphnia magna. Environmental Toxicology and Chemistry, v. 36, (7), 19091916. https://doi.org/10.1002/etc.3714.

Perschbacher, P.W., 2005. Temperature effects on acute copper toxicity to juvenile channel catfish Ictalurus punctatus. Aquaculture, v. 243, (1-4), 225228. https://doi.org/10.1016/j.aquaculture.2004.10.006.

Philippe, C.; Hautekiet, P.; Gregoir, A. F.; Thore, E. S. J.; Pinceel, T. S. R.; Brendonck L.; De Boeck, G., 2018. Combined effects of cádmium exposure and temperature on the annual killifish (Nothobranchius furzeri). Environmental Toxicology and Chemistry, 37, (9), 2361-2371. https://doi.org/10.1002/ETC.4182.

Pinheiro, J.P.S.; Assis, C.B.; Muñoz-Peñuela, M.; Barbosa Júnior, F.; Correia, T.G.; Moreira, R.G., 2019. Water temperature and acid pH influence the cytotoxic and genotoxic effects of aluminum in the freshwater teleost Astyanax altiparanae (Teleostei: Characidae). Chemosphere, v. 220, 266-274. https://doi. org/10.1016/j.chemosphere.2018.12.143.

Pound, K.L.; Larson, C.A.; Passy, S.I., 2021. Current distributions and future climate-driven changes in diatoms, insects and fish in US streams. Global Ecology and Biogeography, 30, 63-78. https://doi.org/10.1111/geb.13193.

Qiu, J., 2012. Trouble on the Yangtze. Science, v. 336, (6079), 288-291. https:// doi.org/10.1126/science.336.6079.288.

Radinger, J.; Hölker, F.; Horký, P.; Slavík, O.; Dendoncker, N.; Wolter, C., 2016. Synergistic and antagonistic interactions of future land use and climate change on river fish assemblages. Global Change Biology, v. 22, (4), 1505-1522. https:// doi.org/10.1111/gcb.13183.

Raptis, C.E.; van Vliet, M.T.H.; Pfister, S. 2016. Global thermal pollution of rivers from thermoelectric power plants. Environmental Research Letters, v. 11, 104011. https://doi.org/10.1088/1748-9326/11/10/104011. 
Raymundo, L.B.; Rocha, O.; Moreira, R.A.; Miguel, M.; Daam, M.A., 2019. Sensitivity of tropical cladocerans to chlorpyrifos and other insecticides as compared to their temperate counterparts. Chemosphere, v. 220, 937-942. https://doi.org/10.1016/j.chemosphere.2019.01.005.

Rehwoldt, R.; Menapace, L.W.; Nerrie, B.; Alessandrello, D., 1972. The effect of increased temperature upon the acute toxicity of some heavy metal ions. Bulletin of Environmental Contamination and Toxicology, v. 8, (2), 91-96. https://doi.org/10.1007/BF01684513.

Salazar-Lugo, R.; León, A.; Lemus, M., 2009. Efecto del cadmio y de la temperatura sobre el conteo de células sanguíneas del pez dulceacuícola Colossoma macropomum. Revista Científica (Maracaibo), v. 19, (1), 1-11.

Sampaio, R.F.; Mancini, M.C., 2007. Estudos de Revisão Sistemática: um guia para síntese criteriosa da evidência científica. Brazilian Journal of Physical Therapy, v. 11, (1), 77-82. http://dx.doi.org/10.1590/S141335552007000100013.

Sassi, A.; Annabi, A.; Kessabi, K.; Kerkeni, A.; Said, K.; Messaoudi, I., 2010. Influence of high temperature on cadmium-induced skeletal deformities in juvenile mosquitofish (Gambusia affinis). Fish Physiology and Biochemistry, v. 36, (3), 403-409. https://doi.org/10.1007/s10695-009-9307-9.

Schiedek, D.; Sundelinet, B.; Readman, J.W.; Macdonald, R.W., 2007. Interactions between climate change and contaminants. Marine Pollution Bulletin, v. 54, (12), 1845-1856. https://doi.org/10.1016/j. marpolbul.2007.09.020.

Silva, L.C.M.; Daam, M.A.; Gusmao, F., 2020. Acclimation alters glyphosate temperature-dependent toxicity: Implications for risk assessment under climate change. Journal of Hazardous Materials, v. 385, 121512. https://doi. org/10.1016/j.jhazmat.2019.121512.

Silva, V.; Marques, C.R.; Campos, I.; Vidal, T.; Keizer, J.J.; Gonçalves, F.; Abrantes, N., 2018. Combined effect of copper sulfate and water temperature on key freshwater trophic levels-approaching potential climatic change scenarios. Ecotoxicology and Environmental Safety, v. 148, 384-392. https:// doi.org/10.1016/j.ecoenv.2017.10.035.

Stuhlbacher, A.; Bradley, M.C.; Naylor, C.; Calow, P., 1993. Variation in the development of cadmium resistance in Daphnia magna Straus; effect of temperature, nutrition, age and genotype. Environmental Pollution, v. 80, (2), 153-158. https://doi.org/10.1016/0269-7491(93)90141-A.

Tsui, M.T.K.; Wang, W.X., 2004. Temperature influences on the accumulation and elimination of mercury in a freshwater cladoceran, Daphnia magna. Aquatic Toxicology, v. 70, (3), 245-256. https://doi.org/10.1016/j. aquatox.2004.09.006.
Val, J.; Muñiz, S.; Gomà J.; Navarro, E., 2016. Influence of global changerelated impacts on the mercury toxicity of freshwater algal communities. Science of the Total Environment, v. 540, 53-62. https://doi.org/10.1016/j. scitotenv.2015.05.042.

Van Ginneken, M.; Blust, R.; Bervoets, L., 2019. The impact of temperature on metal mixture stress: Sublethal effects on the freshwater isopod Asellus aquaticus. Environmental Research, v. 169, 52-61. https://doi.org/10.1016/j. envres.2018.10.025.

Vardhan, K.H.; Kumar, P.S.; Panda, R.C., 2019. A review on heavy metal pollution, toxicity and remedial measures: current trends and future perspectives. Journal of Molecular Liquids, v. 290, 111197. https://doi. org/10.1016/j.molliq.2019.111197.

Vergauwen, L.; Hagenaars, A.; Blust, R.; Knapen, D., 2013. Temperature dependence of long-term cadmium toxicity in the zebrafish is not explained by liver oxidative stress: evidence from transcript expression to physiology. Aquatic Toxicology, v. 126, 52-62. https://doi.org/10.1016/j. aquatox.2012.10.004.

Wetzel, R.G., 2001. Limnology: lake and river ecosystems. Academic Press, San Diego, 1006 pp.

Xu, X.; Wang, Y.-C.; Kalcic, M.; Muenich, R.L.; Yang, Y.C.E.; Scavia, D., 2019. Evaluating the impact of climate change on fluvial flood risk in a mixed-use watershed. Environmental Modelling and Software, v. 122, 104031. https://doi. org/10.1016/j.envsoft.2017.07.013.

Yong, W.-K.; Sim, K.S.; Poong, S.W.; Wei, D.; Phang, S.M.; Lim, P.E., 2018. Interactive effects of temperature and copper toxicity on photosynthetic efficiency and metabolic plasticity in Scenedesmus quadricauda (Chlorophyceae). Journal of Applied Phycology, v. 30, (6), 3029-3041. https:// doi.org/10.1007/s10811-018-1574-3.

Zagatto, P.A.; Bertoletti, E., 2006. Ecotoxicologia aquática: princípios e aplicações. Rima, São Carlos, 464 pp.

Zebral, Y.D.; Fonseca, J.S.; Roza, M.; Costa, P.G.; Robaldo, R.B.; Bianchini, A., 2020. Combining elevated temperature with waterborne copper: impacts on the energy metabolism of the killifish Poecilia vivipara. Chemosphere, v. 253, 126631. https://doi.org/10.1016/j.chemosphere.2020.126631.

Zebral, Y.D.; Roza, M.; Fonseca, J.S.; Costa, P.G.; De Oliveira, C.S.; Zocke, T.G.; Dal Pizzol, J.L.; Robaldo, R.B.; Bianchini, A., 2019. Waterborne copper is more toxic to the killifish Poecilia vivipara in elevated temperatures: Linking oxidative stress in the liver with reduced organismal thermal performance. Aquatic Toxicology, v. 209, 142-149. https://doi.org/10.1016/j. aquatox.2019.02.005. 